\title{
Transatlantica
}

Revue d'études américaines. American Studies Journal

\section{Rachel Sykes, The Quiet Contemporary American Novel}

\section{Yannicke Chupin}

\section{(2) OpenEdition}

1 Journals

Electronic version

URL: https://journals.openedition.org/transatlantica/14948

DOI: 10.4000/transatlantica. 14948

ISSN: 1765-2766

Publisher

Association française d'Etudes Américaines (AFEA)

\section{Electronic reference}

Yannicke Chupin, "Rachel Sykes, The Quiet Contemporary American Novel", Transatlantica [Online], 2 I 2019, Online since 15 September 2020, connection on 03 February 2023. URL: http://

journals.openedition.org/transatlantica/14948 ; DOI: https://doi.org/10.4000/transatlantica. 14948

This text was automatically generated on 3 February 2023.

\section{(c) (1) () $\Theta$}

Creative Commons - Attribution-NonCommercial-NoDerivatives 4.0 International - CC BY-NC-ND 4.0 https://creativecommons.org/licenses/by-nc-nd/4.0/ 


\title{
Rachel Sykes, The Quiet Contemporary American Novel
}

\author{
Yannicke Chupin
}

\section{REFERENCES}

Rachel Sykes, The Quiet Contemporary American Novel, Manchester:Manchester University Press, coll. Contemporary American and Canadian Writers, 2018, 226 pages, ISBN 978 1526108876 , Hardcover $£ 80.00$

1 In The Quiet Contemporary American Novel, Rachel Sykes boldly attempts to define and problematize what she identifies as a neglected area in the study of twenty-firstcentury American fiction and that she names "quiet novels." Set within a large framework of two centuries of American culture, her well-researched monograph brings into focus nine contemporary novels by Teju Cole, Ben Lerner, Paul Harding, Richard Powers, Lynne Tillman and Marilynne Robinson as well as discussing the works of many other authors, from Thoreau, Melville and Hawthorne to Marcel Proust, Virginia Woolf, Thomas Pynchon, Mark Haddon, Jonathan Safran Foer and Sheila Heiti.

"Quiet" is not a word usually associated with the dominant features of American culture. Drama, noise, speed and extravagance are often privileged in the depiction of American cultural identity. However, Sykes reminds us of a long tradition of "quiet characters" and undramatic narratives in the history of nineteenth- and twentiethcentury literature-citing Bartleby and Hester Prynne as cases in point. The phrase "quiet novel" has been circulating since the 1860 s in literary journalism, after which time it entered the vocabulary of literary criticism, but it has never really been developed or explored in literary studies. The subject of this monograph feels timely as a great number of twenty-first-century novelists have concentrated their attention on what Henry James named "the chamber of consciousness" (141), unfolding the lives of introverted characters, with novels set in isolated rural locations, generally going against the grain of bestselling and "incredibly loud" fiction in a post 9/11 world. 
Publishers themselves, Sykes demonstrates, have become more open to those longrejected quiet narratives and have been able to bring them to surprisingly large audiences. To unite a large body of works that respond to her characterization, Sykes offers a definition of the quiet novel based on four features that concern characterization, narrative strategies and subject. According to Sykes, "quiet novels" typically portray (1) introverts and scholarly figures prone to contemplation or introspection (2) in a narrative that proceeds at a slow pace and lacks in action (3) while the movement of thoughts and consciousness of the narrator is central. The last feature is also, by her own admission, the most difficult to define. More than just a feature, it is also a key to the whole notion of quiet as it problematizes its potential value in American fiction. If the ruminations of an introvert in a narrative where little happens are not likely to stir interest, a quiet novel, through its valorization of reflection, might result in an efficient questioning of the contemporary world, Sykes argues. According to her, narrators of most quiet novels, although removed from the hum and roar of consumerist America, are not hermits disengaged from the social world but characters who find in quietness a more expressive way to engage with the contemporary moment. One of the key ideas Sykes offers to account for the resurgence of quiet voices in twenty-first-century fiction resides in their disruptive potential. Sykes draws her initial point from Kevin Quashie's argument in The Sovereignty of Quiet in African American Culture (2012). In an African American culture dominated by cultural violence, Quashie sees in the anomalous nature of the "quiet" new and stronger ways of expressing black subjectivity. Considering contemporary American fiction, Sykes draws similar conclusions, noting how quiet novels might read as a strong commentary and sometimes a strong act of protest against most contemporary novels' enslavement to loud mainstream culture.

3 Sykes' book is divided into five chapters that include historical accounts of noise and quiet in Western culture, as well as analyses of contemporary American fiction. Two chapters (two and five) lay a strong emphasis on examining "the quiet" in contrast to the loudness of New York, 9/11 and its aftermath, while two others delve into the concepts of temporality and cognition in quiet narratives. In every chapter, Rachel Sykes grounds her analyses within a theoretical, historical and cultural framework, relying on the work of a wide range of specialists, from literary and cultural theorists, historians and philosophers to cognitive scientists, sociologists and sound studies specialists.

4 The first chapter offers a historical approach to the notion of "quiet novel" and provides an overview of the development of loud culture in a post-industrial, modern and then postmodern world. After exploring the unAmericanness of "quiet," the chapter brings together reflections on the changes brought by European modernism and urbanization and how they reinforced the dichotomy of noise versus the quiet shelter needed for intellectual, artistic and creative reflection. While the advent of psychoanalysis is paralleled in literature by a growing focus on consciousness, cities continue to expand, their growing noise eating up individuals' peace of mind in all social classes. A few writers may have been enthralled by the narrative possibilities offered by urban speed, traffic and noise-Sykes cites Ulysses as a case in point-but in most modernist novels, noise is depicted as a pollutive factor that denies the individual the possibility of reflection. 
5 The second chapter tries to define literary quiet in relation with everything that it is not, paying attention to the ever-growing noise of contemporary novels concerned with the "sonic afterlife of 9/11" (48). Here, the author positions herself in the critical history of literary responses to $9 / 11$, deploring the rhetoric of singularity and rupture that seeped into most literary responses to the attacks. Central to her argument is the binary notion of rupture and continuity as she claims that many novelists rushed to singularize the event and therefore failed to recognize in it an extension of a rampant culture of noise and violence in their postmodern and media culture. The result, she argues, is a limitation of the possible diversity of representations of the attacks. Reexamining the notion of literary genres through the lens of Frederic Jameson's theories, she criticizes the systematic categorization of every book integrating the event into a new genre now called "9/11 fiction" or "post 9/11 fiction," suggesting instead that the only common factor in all these novels is the exacerbation of an ongoing crisis of representation. Sykes indeed calls for a "reappraisal of ' $9 / 11$ ' fiction within a longer history of noise in America" (49). Instead of resorting to quietness and reflection and attempting to find different means to connect their novels with the contemporary world, the authors of noise-filled 9/11 fictions have been concerned with writing increasingly louder fiction in order to meet the clamor of the tragedy itself, a need Sykes identifies in her reading of many male authors like Don DeLillo, Jonathan Safran Foer or John Updike. Singling out Amy Waldman's debut novel The Submission as one of the kind that eschews this problem, Sykes praises the writer's focus on the process of memorialization, the emphasis on the privacy and silence needed to make sense of the historical impact of the attacks, and by so doing "restoring an aesthetic of quiet to the memorialization of an event that has been conceived primarily by its noise" (67).

Chapter three turns to the very nature of "quiet" with a close reading of the aesthetics of Marilynne Robinson's Gilead novels and Paul Harding's Tinker (2008). The choice of Robinson's novels, all set in rural locations in the mid-twentieth century, but relying on distinct narrative strategies, enables Sykes to firmly ground her definition of "quiet" within the narrative aesthetic that she describes in her introduction, all the while analyzing the definition's various nuances, especially in regard to the complex engagement of the quiet novel with its contemporaneity. The second part of the chapter addresses the notion of temporality, offering connections to the recent "temporal turn" in philosophical studies. The eventlessness of quiet novels, she suggests, is what restores the individual's capacity for reflection in the present. The temporal abstraction in which Robinson and Harding set their novels allows them to subdue the cultural noise of contemporary culture represented by political and historical events, or digital technologies, so that they only constitute a "vague scenery to the emotional landscape of the characters" (91), therefore restoring the value of time against the endless rush of our society.

7 Chapter four is concerned with the "novels of cognition," which Sykes considers as another form of the quiet novel. This kind of fiction, which was influenced by earlytwenty-first-century cognitive approaches within literary studies, recalls the modernists' fascination with the movement of consciousness but expands it into an interest in the theories of the brain and the findings of neuroscience. According to Sykes, the novel of cognition manifests the same preoccupation with interiority although interiority is submitted there to crises and accidents and is therefore 
structurally unstable (118). Brain damage or characters recovering from traumas have been privileged subjects in this kind of fiction, like Mark Haddon's celebrated The Curious Incident of the Dog in the Night-time (2003) or Jonathan Lethem's Motherless Brooklyn (1999). In this chapter, Sykes bases her arguments on her readings of Richard Powers' The Echo Maker (2006) and Lynne Tillman's American Genius (2006), showing how they "detail the machinations of consciousness in order to drive the narrative forward without the passing of action or event" (142). Usually keen on quietly representing mental unrest or "unquiet states of mind" (118), these novels are more interested in "process rather than progress" and reaffirm Sykes' interest in the quiet novel's focus on continuity.

8 In the final chapter, Sykes returns to the problematic relation of the "quiet novel" with the urban, this time examining the contradictory possibility of the emergence of a "quiet novel" from the urban environment. The chapter is remarkable in the way it nuances the points previously established and explores the possible limits of quiet novels. The two novels considered, Ben Lerner's Leaving the Atocha Station and Teju Cole's Open City, slow-paced and reflexive novels in which narrative progression follows the sometimes drowsy perambulations of two narrators in the city, are undeniably "quiet" but they also both dramatize the irreducible tension between noisy environment and the need for the quietness both narrators seek out. Although they are keen observers of the cacophonous city, Julius (Open City) and Adam (Leaving the Atocha Station) are also young privileged book-and-art lovers who find themselves attracted to the quiet spaces of the city, its museums and galleries. For Sykes, both narrators reactivate the ambivalence of the nineteenth-century flâneur, especially when considered from the angle of their participation in the life of the city. In a world where the urban production of noise has reached unprecedented levels, the contemporary flâneur seems to perpetuate the act of protest inherited from his nineteenth-century ancestor through his "counter-hegemonic attempt to install reflection and [...] quiet at the center of the urban landscape" (159). Teju Cole's novel verifies this claim as it is structured by his strolling and internal recollections of family history more than by the meaningful events that might result from his interaction with the vibrant characters he encounters. Sykes is interested in how both narrators more often than not exclude themselves from the ongoing life of the city, from social or political engagement, to the point of silencing or at least quieting within their narratives the most significant intrusions of history-in-the making, as for instance the 2004 Atocha station bombings in Madrid or the voices of migrants in Open City. Sykes concludes with the suggestion that these novels might therefore also represent the dangers of the quiet when it is assimilated to a solipsistic retreat.

9 Rachel Sykes' impressive study feels relevant at a time when the introspective genre of "autofiction" and the success of recent novels such as Jenny Offill's Department of Speculation (2014) and Weather (2020), Sheila Heiti's How Should a Person Be? (2010) and Kate Zambreno's recent Drifts (2020) attest to the renewed interest in the novels of consciousness. Sykes' pointed mention of John William's Stoner, a novel humble in subject and quiet in tone that sold only 2000 copies when it was released in 1965 but became an international bestseller when it was rediscovered in 2006, is another example that shows how quietness is in tune with twenty-first-century readers' needs.

This study is all the more valuable as it makes its argument within the context of the thoroughly documented culture of late capitalism. It addresses an impressive field of 
studies, including some illuminating investigations into the history of sounds in the city. One notes the references to the works of Karen Bijsterveld, as for instance when she remarks how Western culture has always prioritized sight over sound, because "our culture is deadly afraid of silence and of the passiveness associated with the absence of sound" (156). This leads Sykes to some nuanced arguments about the role of sounds as a means "to reaffirm our humanity, relationality to others" (156) and complexify the tense relations between quiet and noise. The dynamic of the book relies a lot on that essential dichotomy, which justifies the emphasis on sounds in Chapters two and five. The chapter on what Sykes refuses to call " $9 / 11$ fiction" offers innovative views that invite further discussion. Her reading of Falling Man for instance emphasizes the writer's representation of loudness and clamor-which is inherent to the event-but does that make of Falling Man a loud novel? Is the event itself the subject of the novel or is it not instead a rather slow, long and erring process of recovery? DeLillo has already addressed topical events in the history of his country such as the assassination of J.F. Kennedy in Libra, however, as the author himself remarked in an interview: "in Libra, the entire thrust of the novel is toward an event that is the assassination of President Kennedy, and in Falling Man, the novel moves away from an event." ${ }^{1}$ All in all, this also strengthens Sykes's acknowledgement that the quiet novel's value cannot be dissociated from the tension exerted by surrounding noise; and the richest part of this compelling and impressive study lies in its thorough exploration of the creative dialectic that articulates loud and quiet in American literature.

\section{NOTES}

1. Melissa Block, "Falling Man Maps Emotional Aftermath of Sept. 11," NPR, All Things Considered, 20 June 2007: https://www.npr.org/2007/06/20/11223451/falling-man-maps-emotionalaftermath-of-sept-11, accessed 22 September 2020.

INDEX

Subjects: Recensions

\section{AUTHORS}

\section{YANNICKE CHUPIN}

CY Cergy Paris Université/En délégation CNRS 2020-2021, Université de Paris, LARCA, CNRS 